\title{
Sistem Pendukung Keputusan Lomba Kinerja Kelurahan dengan Metode AHP
}

\author{
Puspa Eosina* , Suratun, Fitri Mulyani \\ Program Studi Teknik Informatika, Universitas Ibn Khaldun Bogor, Indonesia \\ *e-mail koresponden: puspa.eosina@ft.uika-bogor.ac.id
}

\begin{abstract}
Abstrak
Tingkat keberhasilan pembangunan dikelurahan diukur dengan kriteria-kriteria tertentu. Badan Pemberdayaan Masyarakat dan Keluarga Berencana (BPMKB) Kota Bogor setiap tahunnya melaksanakan lomba kinerja kelurahan untuk mengevaluasinya. Dalam penentuan penetapan pemenang lomba kinerja kelurahan dinilai pada seleksi presentasi dan kunjungan lapang masih menghitung secara manual sehingga dibutuhkan Sistem pendukung Keputusan (SPK) yang mampu memberikan solusi alternatif untuk proses penilaian presentasi dan kunjungan lapang. Metode yang digunakan dalam sistem pendukung keputusan lomba kinerja kelurahan ini adalah metode Analytical Hierarchy Process (AHP), yang digunakan untuk pembobotan kriteria dan alternatif. SPK ini menggunakan 3 jenis hak akses (roles) yaitu admin, juri dan pimpinan. Keluaran sistem adalah hasil angka perhitungan AHP yang merupakan rekomendasi bagi pihak pengambil keputusan dalam penentuan pemenang perlombaan. Hasil perhitungan menampikan bobo-bobot kriteria, yaitu : 0,167 untuk kriteria penguasaan materi ekspos, 0,056 untuk kriteria penampilan pemberi materi ekspos, 0,111 untuk kriteria ketepatan waktu ekspos, 0,222 untuk kriteria produk unggulan, dan 0,444 untuk kriteria inovasi. Dengan nilai bobot tersebut, ditampilkan hasil rekomendasi untuk pemenang dengan urutan ranking terbaik yaitu kelurahan Menteng, kelurahan Cibadak, kelurahan Ciparigi, kelurahan Katulampa, kelurahan Cikaret, dan kelurahan Babakan Pasar.
\end{abstract}

Katakunci: AHP; Kinerja Kelurahan; SPK

\begin{abstract}
The level of success of the development in the village government is measured by certain criteria. The Bogor City of Badan Pemberdayaan Masyarakat dan Keluarga Berencana (BPMKB) annually conducts urban village government performance competitions to evaluate it. In determining the determination of the winners of the kelurahan performance competition, the presentation selection and field visits were still counted manually so that a Decision Support System (DSS) was needed that was able to provide alternative solutions for the presentation process and field visits. The method used in the decision support system for this kelurahan performance competition is the Analytical Hierarchy Process (AHP) method, which is used for weighting criteria and alternatives. This DSS uses 3 types of access rights (roles), namely admin, jury and leader. System output is the result of the AHP calculation number which is a recommendation for decision makers in determining the winner of the race. The calculation results show the bobo-weight criteria, namely: 0.167 for mastery of exposure material criteria, 0.056 for the criteria for exposure material exposures, 0.111 for the criteria for exposure time, 0.222 for the criteria of superior products, and 0.444 for the
\end{abstract}


criteria of innovation. With these weight values, the results of recommendations for winners with the best ranking are displayed, namely Menteng Village, Cibadak Village, Ciparigi Village, Katulampa Village, Cikaret Sub-District, and Babakan Pasar Village.

Keywords: AHP; DSS; performance of village government

\section{PENDAHULUAN}

Perkembangan teknologi informasi yang sedemikian pesat, dapat dimanfaatkan untuk membantu, mengkonsolodasi, mentransformasi informasi dan menentukan keputusan pada top management level (manager), yang dikenal sebagai Sistem Pendukung Keputusan (SPK)[1]. Sistem tersebut dapat mengolah informasi untuk mendukung keputusan dengan menawarkan alternatif-alternatif solusi yang terbaik [2-6]. Hal ini dapat dimanfaatkan dalam membantu Badan Pemberdayaan Masyarakat dan Keluarga Berencana (BPMKB) Kota Bogor untuk menentukan kelurahan terbaik setiap tahunnya. Dalam menentukan kelurahan terbaik, BPMKB kota Bogor mengadakan lomba antar kelurahan yang akan menilai kinerja setiap kelurahan. Proses lomba kinerja kelurahan dilakukan dengan tiga jenis penilaian, yakni : seleksi administrasi, seleksi presentasi, dan seleksi kunjungan lapang.

Pada penilaian administrasi ini sudah ada aturan dan sistem tersendiri yang digunakan untuk menghitung skor hasil penilaian. Untuk seleksi presentasi dinilai dari penguasaan materi, penampilan emberi materi, dan ketepatan waktu presentasi. Sedangkan untuk kunjungan lapang dinilai dari : produk unggulan dan inovasi, dengan mengacu Permendagri nomor 13 tahun 2007 tentang pedoman penyelenggaraan perlombaan desa dan kelurahan [7], [8]. Selama ini untuk memilih kinerja kelurahan mana yang terbaik dalam proses penilaian seleksi presentasi dan seleksi kunjungan lapang pada proses perlombaan kelurahan tingkat Kota Bogor, tim penilai yang dibentuk oleh Walikota Bogor masih kesulitan dalam menentukan kinerja kelurahan terbaik dikarenakan adanya perbedaan pendapat antara tim penilai satu dengan yang lainnya dalam menentukan pemenangnya. Untuk hal itu, maka perlu dibuat suatu SPK yang dapat membantu memberikan rekomendasi hasil yang lebih akurat, lebih efektif, dan lebih efisien.

Analytical Hierarchy Process (AHP) adalah suatu model pendukung keputusan yang dikembangkan oleh Thomas L. Saaty [9]. AHP menguraikan masalah multifaktor atau multikriteria yang kompleks menjadi suatu hirarki [10], [11], [12]. Dengan menggunakan metode AHP, penelitian ini bertujuan untuk membangun SPK untuk penentuan kelurahan terbaik pada Lomba Kinerja Kelurahan Tingkat Kota Bogor.

\section{METODE PENELITIAN}

Pada langkah awal, dilakukan pengumpulan data dengan cara wawancara, observasi serta studi literatur. Wawancara dilakukan kepada Kepala Bidang Penguatan Kelembagaan dan Pengembangan Partisipasi Masyarakat (PKPPM) di BPMKB Kota Bogor selaku penanggungjawab pada kegiatan lomba kinerja kelurahan. Tujuan wawancara ini untuk mengetahui tata cara dalam lomba kinerja kelurahan terbaik tingkat Kota Bogor. Pada tahap observasi dilakukan pengamatan yang lebih mendalam pada instansi yang dijadikan obyek penelitian, khususnya di BPMKB Kota Bogor. Dimana observasi ini dilakukan untuk mengumpulkan data dan informasi dengan cara meninjau dan mengamati secara langsung kegiatan yang terjadi dilapangan. Sedangkan pada tahap studi literatur dicari metode yang cocok yang mendukung pelaksanaan penelitian. 


\section{a. Analisis Data menggunakan AHP}

Berdasarkan data yang diperoleh, maka digunakan 5 (lima) kriteria dalam perhitungan metode AHP yaitu penguasaan materi ekspos, penampilan pemberi materi ekspos, ketepatan waktu ekspos, produk unggulan, dan inovasi, dengan 6 (enam) alternatif kelurahan yang akan diberikan nilai, antara lain: Ciparigi, Menteng, Babakan Pasar, Katulampa, Cikaret, dan Cibadak yang selajutnya, dilakukan pembentukan hierarki. Diagram hierarki pada metode AHP memiliki dua tingkatan, yaitu kriteria dan alternatif [11]. Diagram hierarki yang terbentuk seperti yang ditunjukkan pada Gambar 1.

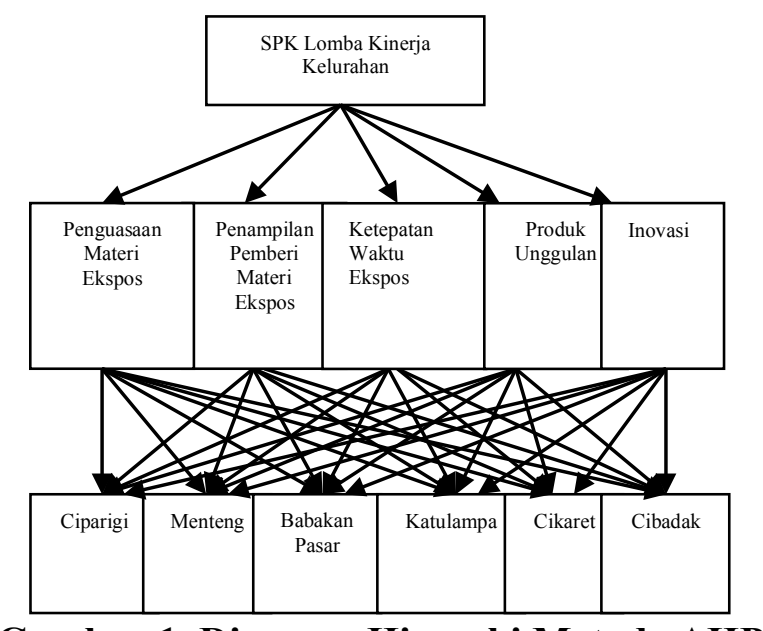

Gambar 1. Diagram Hierarki Metode AHP

\section{b. Pembobotan Kriteria dan Alternatif}

Pembobotan kriteria dan alternatif dilakukan dengan perbandingan berpasangan (pairwise comparisons). Menurut [6], untuk berbagai persoalan, skala 1 sampai 9 adalah skala terbaik untuk mengekspresikan pendapat. Nilai dan definisi pendapat kualitatif dari skala perbandingan Saaty bisa diukur menggunakan tabel analisis seperti yang disajikan pada Tabel 1 [11]. Nilai-nilai perbandingan relatif dari seluruh alternatif kriteria bisa disesuaikan dengan judgement yang telah ditentukan untuk menghasilkan bobot dan prioritas. Bobot dan prioritas dihitung dengan memanipulasi matriks atau melalui penyelesaian persamaan matematika [10]. Matriks akan diolah untuk menentukan bobot dari kriteria, yaitu dengan jalan menentukan nilai eigen (eigen vector). Prosedur untuk mendapatkan nilai eigen adalah sebagai berikut:

Langkah 1, ubah matriks menjadi bilangan desimal

Langkah 2, kuadratkan matriks tsb

Langkah 3, hitung jumlah nilai dari setiap baris, kemudian lakukan normalisasi

Ulangi proses pada langkah 2 dan langkah 3 dan bandingkan hasilnya dengan hasil sebelumnya dengan menghitung perbedaannya. Hentikan proses pengulangan ini, bila nilai perbedaan lebih kecil dari suatu nilai batas tertentu yang kita inginkan.

\section{Pembobotan Alternatif}

Dilakukan dengan menyusun matriks berpasangan untuk alternatif-alternatif bagi setiap kriteria, dengan menghitung nilai eigen alternative dari kriteria yang dilanjutkan dengan pemeriksaan Logical Consistency (Konsistensi Logis). Konsistensi memiliki dua makna. Pertama, objek-objek yang serupa bila dikelompokkan sesuai dengan keseragaman dan relevansi. Kedua, menyangkut tingkat hubungan antar objek yang didasarkan pada kriteria tertentu [9]. Penyelesaian ini dilakukan dengan perhitungan indeks konsistensi (CI). 
Pengukuran ini dimaksudkan untuk mengetahui konsistensi jawaban yang akan berpengaruh kepada kesahihan, dengan rumus :

$$
C I=\frac{p-n}{n-1}
$$

Dimana :

$\mathrm{n}$ adalah banyaknya kriteria

$\mathrm{CI}=$ Rasio penyimpangan (deviasi) konsistensi (consistency index)

$\mathrm{p}=$ Rata-rata Consistency Vector

Tabel 1. Skala Saaty

\begin{tabular}{clll}
\hline $\begin{array}{c}\text { Tingkat } \\
\text { Kepentingan }\end{array}$ & \multicolumn{1}{c}{ Keterangan } & \\
\hline 1 & $\begin{array}{l}\text { Kriteria/ Alternatif sama penting dengan kriteria/ } \\
\text { alternatif B }\end{array}$ & \\
3 & A sedikit lebih penting dari B & \\
5 & $\begin{array}{l}\text { A jelas lebih penting dari B } \\
\text { A sangat jelas lebih penting dari B }\end{array}$ \\
9 & $\begin{array}{l}\text { Mutlak lebih penting dari B } \\
\text { Apabila ragu-ragu antara dua nilai yang berdekatan }\end{array}$ \\
\hline
\end{tabular}

\section{Consistency Ratio (CR)}

Consistencty Ratio (CR) merupakan parameter yang digunakan untuk memeriksa apakah perbandingan berpasangan telah dilakukan dengan konsekuen atau tidak. Untuk menghitung CR, dibutuhkan Nilai Index Random (IR) yang sudah ditentukan seperti yang disajikan pada Tabel 2. Nilai CR dihitung menggunakan rumus :

Dimana:

$$
C R=\frac{C I}{I R}
$$

$\mathrm{CR}=$ Consistency Ratio

$\mathrm{CI}=$ Consistency Index

$\mathrm{IR}=$ Indeks Random Consistency

Jika nilai CR lebih dari 10\%, maka penilaian data judgment harus diperbaiki. Namun jika CR kurang atau sama dengan 0,1, maka hasil perhitungan bisa dinyatakan benar [9].

\section{c. Menentukan Prioritas Kriteria}

Langkah-langkah yang harus dilakukan dalam menentukan prioritas kriteria adalah: memasukkan nilai perbandingan tingkat kepentingan kriteria berdasarkan penilaian yang dilakukan oleh 3 orang responden yang mewakili tim penilai lomba kinerja kelurahan. Adapun matrik hasil perbandingan berpasangan berdasarkan kriteria [13], [14], [15] dapat dilihat pada table 3

\section{d. Menentukan Prioritas Alternatif}

Penentuan prioritas alternatif dilakukan dengan cara yang sama seperti menentukan prioritas kriteria [13], [14], [15]. Susunan matrik alternatif berpasangan berdasarkan kriteria penguasaan materi, dapat dilihat pada Tabel 4. Susunan matrik berpasangan alternatif berdasarkan kriteria penampilan pemberi materi, dapat dilihat pada Tabel 5. Susunan matrik berpasangan alternatif berdasarkan kriteria ketepatan waktu, selengkapnya dapat dilihat pada Tabel 6. Susunan matrik berpasangan alternatif berdasarkan kriteria produk unggulan, 
selengkapnya dapat dilihat pada Tabel 7. Susunan matrik berpasangan alternatif berdasarkan kriteria inovasi, selengkapnya dapat dilihat pada Tabel 8

Tabel 2. DaftarIndeks Random Consistency

\begin{tabular}{ll}
\hline $\mathbf{n}$ & $\mathbf{R I}$ \\
\hline 1 & 0.00 \\
2 & 0.00 \\
3 & 0.58 \\
4 & 0.90 \\
5 & 1.12 \\
6 & 1.24 \\
7 & 1.32 \\
8 & 1.41 \\
9 & 1.45 \\
10 & 1.49 \\
11 & 1.51 \\
12 & 1.48 \\
13 & 1.56 \\
14 & 1.57 \\
15 & 1.59 \\
\hline
\end{tabular}

Tabel 3 Matrik Hasil Perbandingan Berpasangan Berdasarkan Kriteria

\begin{tabular}{lccccc}
\hline Goal & $\begin{array}{c}\text { Penguasaan } \\
\text { Materi } \\
\text { Ekspos }\end{array}$ & $\begin{array}{c}\text { Penampilan } \\
\text { Pemberi Materi } \\
\text { Ekspos }\end{array}$ & $\begin{array}{c}\text { Ketepatan } \\
\text { Waktu } \\
\text { Ekspos }\end{array}$ & $\begin{array}{c}\text { Produk } \\
\text { Unggulan }\end{array}$ & Inovasi \\
\hline $\begin{array}{l}\text { Penguasaan } \\
\text { Materi Ekspos }\end{array}$ & 1 & $3 / 1$ & $3 / 2$ & $3 / 4$ & $3 / 8$ \\
$\begin{array}{l}\text { Penampilan } \\
\text { Pemberi Materi }\end{array}$ & $1 / 3$ & 1 & $1 / 2$ & $1 / 4$ & $1 / 8$ \\
$\begin{array}{l}\text { Ekspos } \\
\text { Ketepatan }\end{array}$ & & & & & \\
$\begin{array}{l}\text { Waktu Ekspos } \\
\text { Produk }\end{array}$ & $2 / 3$ & $2 / 1$ & 1 & $1 / 2$ & $1 / 4$ \\
$\begin{array}{l}\text { Unggulan } \\
\text { Inovasi }\end{array}$ & $4 / 3$ & $4 / 1$ & $2 / 1$ & 1 & $1 / 2$ \\
\hline
\end{tabular}

Tabel 4. Alternatif Berdasarkan Kriteria Penguasaan Materi Ekspos

\begin{tabular}{lcccccc}
\hline $\begin{array}{l}\text { Penguasaan } \\
\text { Materi Ekspos }\end{array}$ & Ciparigi & Menteng & $\begin{array}{c}\text { Babakan } \\
\text { Pasar }\end{array}$ & Katulampa & Cikaret & Cibadak \\
\hline Ciparigi & 1 & $8 / 9$ & $8 / 6$ & 1 & $8 / 7$ & 1 \\
Menteng & $9 / 8$ & 1 & $9 / 6$ & $9 / 8$ & $9 / 7$ & $9 / 8$ \\
Babakan Pasar & $6 / 8$ & $6 / 9$ & 1 & $6 / 8$ & $6 / 7$ & $6 / 8$ \\
Katulampa & 1 & $8 / 9$ & $8 / 6$ & 1 & $8 / 7$ & 1 \\
Cikaret & $7 / 8$ & $7 / 9$ & $7 / 6$ & $7 / 8$ & 1 & $7 / 8$ \\
Cibadak & 1 & $8 / 9$ & $8 / 6$ & 1 & $8 / 7$ & 1 \\
\hline
\end{tabular}


Tabel 5. Alternatif Berdasarkan Kriteria Penampilan Pemberi Materi Ekspos

\begin{tabular}{lcccccc}
\hline $\begin{array}{l}\text { Penampilan } \\
\begin{array}{l}\text { Pemberi Materi } \\
\text { Ekspos }\end{array}\end{array}$ & Ciparigi & Menteng & $\begin{array}{c}\text { Babakan } \\
\text { Pasar }\end{array}$ & Katulampa & Cikaret & Cibadak \\
\hline Ciparigi & 1 & $8 / 7$ & $8 / 9$ & $8 / 7$ & 1 & $8 / 9$ \\
Menteng & $7 / 8$ & 1 & $7 / 9$ & 1 & $7 / 8$ & $7 / 9$ \\
Babakan Pasar & $9 / 8$ & $9 / 7$ & 1 & $9 / 7$ & $9 / 8$ & 1 \\
Katulampa & $7 / 8$ & 1 & $7 / 9$ & 1 & $7 / 8$ & $7 / 9$ \\
Cikaret & 1 & $8 / 7$ & $8 / 9$ & $8 / 7$ & 1 & $8 / 9$ \\
Cibadak & $9 / 8$ & $9 / 7$ & 1 & $9 / 7$ & $9 / 8$ & 1 \\
\hline
\end{tabular}

Tabel 6. Alternatif Berdasarkan Kriteria Ketepatan Waktu Ekspos

\begin{tabular}{lcccccc}
\hline $\begin{array}{l}\text { Ketepatan Waktu } \\
\text { Ekspos }\end{array}$ & Ciparigi & Menteng & $\begin{array}{c}\text { Babakan } \\
\text { Pasar }\end{array}$ & Katulampa & Cikaret & Cibadak \\
\hline Ciparigi & 1 & $8 / 9$ & $8 / 9$ & $8 / 7$ & 1 & $8 / 7$ \\
Menteng & $9 / 8$ & 1 & 1 & $9 / 7$ & $9 / 8$ & $9 / 7$ \\
Babakan Pasar & $9 / 8$ & 1 & 1 & $9 / 7$ & $9 / 8$ & $9 / 7$ \\
Katulampa & 1 & $7 / 9$ & $7 / 9$ & 1 & $7 / 8$ & 1 \\
Cikaret & 1 & $8 / 9$ & $8 / 9$ & $8 / 7$ & 1 & $8 / 7$ \\
Cibadak & $7 / 8$ & $7 / 9$ & $7 / 9$ & 1 & $7 / 8$ & 1 \\
\hline
\end{tabular}

Tabel 7. Alternatif Berdasarkan Kriteria Produk Unggulan

\begin{tabular}{lrrrrrr}
\hline $\begin{array}{l}\text { Produk } \\
\text { Unggulan }\end{array}$ & Ciparigi & Menteng & $\begin{array}{r}\text { Babakan } \\
\text { Pasar }\end{array}$ & Katulampa & Cikaret & Cibadak \\
\hline Ciparigi & 1 & $8 / 9$ & $8 / 7$ & 1 & $8 / 7$ & $8 / 9$ \\
Menteng & $9 / 8$ & 1 & $9 / 7$ & $9 / 7$ & $9 / 7$ & 1 \\
Babakan Pasar & $7 / 8$ & $7 / 9$ & 1 & $7 / 8$ & 1 & $7 / 9$ \\
Katulampa & 1 & $8 / 9$ & $8 / 7$ & 1 & $8 / 7$ & $8 / 9$ \\
Cikaret & $7 / 8$ & $7 / 9$ & 1 & $7 / 8$ & 1 & $7 / 9$ \\
Cibadak & $9 / 8$ & 1 & $9 / 7$ & $9 / 8$ & $9 / 7$ & 1 \\
\hline
\end{tabular}

Tabel 8 Alternatif Berdasarkan Kriteria Inovasi

\begin{tabular}{lrrrrrr}
\hline $\begin{array}{l}\text { Produk } \\
\text { Unggulan }\end{array}$ & Ciparigi & Menteng & $\begin{array}{r}\text { Babakan } \\
\text { Pasar }\end{array}$ & Katulampa & Cikaret & Cibadak \\
\hline Ciparigi & 1 & $8 / 9$ & $8 / 7$ & 1 & 1 & $8 / 9$ \\
Menteng & $9 / 8$ & 1 & $9 / 7$ & $9 / 8$ & $9 / 8$ & 1 \\
Babakan Pasar & $7 / 8$ & $7 / 9$ & 1 & $7 / 8$ & $7 / 8$ & $7 / 9$ \\
Katulampa & 1 & $8 / 9$ & $8 / 7$ & 1 & 1 & $8 / 9$ \\
Cikaret & 1 & $8 / 9$ & $8 / 7$ & 1 & 1 & $8 / 9$ \\
Cibadak & $9 / 8$ & 1 & $9 / 7$ & $9 / 8$ & $9 / 8$ & 1 \\
\hline
\end{tabular}

HASIL DAN PEMBAHASAN 
Berdasarkan nilai eigen pada pada bobot alternatif, maka diketahui bahwa hasil diagram hierarki dengan nilai bobot kriteria dan alternatif per kriteria yang telah diperoleh dapat dilihat pada Gambar 2.

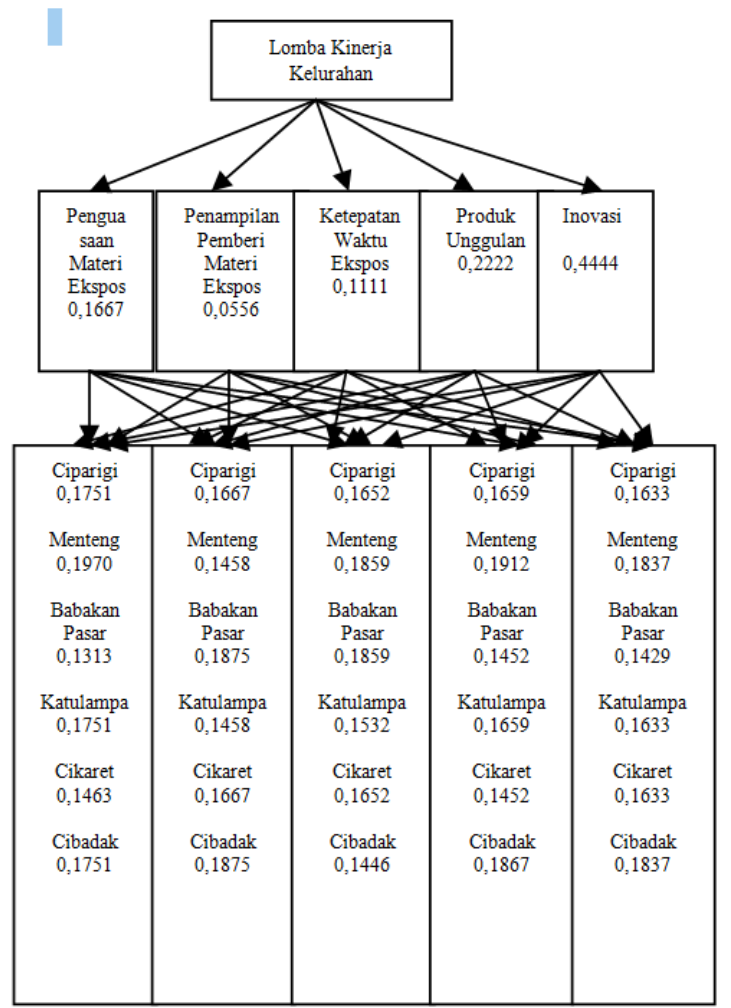

Gambar 2 Diagram Hierarki BobotKriteria dan Alternatif Per Kriteria

Berdasarkan hasil akhir perhitungan menggunakan metode AHP didapatkan rekomendasi alternatif dengan penilaian terbaik sampai terendah. Sehingga dapat disimpulkan bahwa diantara enam alternatif yang dipilih calon kelurahan terbaik yang mempunyai nilai terbesar pada peringkat I yang mempunyai bobot sebesar 0,1857 diperoleh oleh kelurahan Menteng, sedangkan peringkat terendah diperoleh oleh kelurahan Babakan Pasar yang mempunyai bobot sebesar 0,1487. Hasil nilai seluruh peringkat dapat dilihat pada Tabel 9 .

Tabel 9. Peringkat kelurahan terbaik

\begin{tabular}{lcc}
\hline \multicolumn{1}{c}{ Alternatif } & Nilai Hasil & Peringkat Alternatif \\
\hline Ciparigi & 0,1662 & 3 \\
Menteng & 0,1857 & 1 \\
Babakan Pasar & 0,1487 & 6 \\
Katulampa & 0,1637 & 4 \\
Cikaret & 0,1568 & 5 \\
Cibadak & 0,1788 & 2 \\
\hline
\end{tabular}

\section{KESIMPULAN}

Dengan adanya sistem pendukung keputusan lomba kinerja kelurahan menggunakan metode AHP dapat memberikan keputusan alternatif sebagai rekomendasi untuk level managemen. Berdasarkan hasil perhitungan, diperoleh bobot kriteria tertinggi adalah 0,444 yaitu kriteria inovasi dan bobot kriteria terendah 0,056 yaitu kriteria penampilan pemberi materi ekspos. Sedangkan hasil perhitungan bobot alternatif tertinggi 0,185 diperoleh oleh 
kelurahan Menteng dan bobot alternatif terendah 0,149 diperoleh oleh kelurahan Babakan Pasar.

\section{DAFTAR PUSTAKA}

[1] Dwi A D. Sistem Pendukung Keputusan sebagai Alat Bantu Manager. Jurnal Teknologi Informasi DINAMIK. 2006. Vol XI ; 01-07.

[2] Nasution P.P, Sistem Pendukung Keputusan Penambahan Program Studi Dengan Metode Analytical Hierarchy Process (AHP). Majalah Ilmiah Informasi dan Teknologi Ilmiah (INTI). 2014; Vol. III. Nomor: 1. ISSN: 2339-210X.

[3] Gunawan, Ginting M., Fandi H., Pasaribu T.A., Purba B. SPK Pemilihan Komisaris Lapangan Berprestasi Dengan Metode AHP Studi Kasus: KOPDIT CU HATIRONGGA, STMIK Mikrosil Medan. 2015; Vol 16, No 1. ISSN. 1412-0100.

[4] Sanjaya. "Aplikasi Sistem Pendukung Keputusan Untuk Menentukan Transaksi Online Yang Aman Menggunakan Metode Analitical Hierarchy Process (AHP) Berbasis Web (Studi Kasus : Forum Jual Beli kaskus)”. 2012.

[5] Irfan H. Sistem Pendukung Keputusan Rekomendasi Pegawai Teladan Menggunakan Metode AHP (Studi Kasus Di UPT Radio dan TV Diskominfo Kabupaten Bogor), Skripsi Universitas Ibn Khaldun Bogor Fakultas Teknik Informatika, Bogor, 2015.

[6] Hilyah M. Sistem Pendukung Keputusan Untuk Menentukan Mahasiswa Lulusan Terbaik Di Perguruan Tinggi (Studi Kasus STMIK Atma Luhur Pangkalpinang): Seminar Nasional Teknologi Informasi dan Komunikasi (SENTIKA 2012). 2012..

[7] Pemerintah Kota Bogor, Renstra Badan Pemberdayaan Masyarakat dan Keluarga Berencana Kota Bogor 2016-2020.

[8] Peraturan Menteri Dalam Negeri Nomor 13 Tahun 2007 tentang Penyelenggaraan Perlombaan Desa dan Kelurahan, 2009.

[9] Saaty T L. The Three Lawqs of Thought Plus One The Law of Comparisons. Axioms. 2014;3(1):46-49 DOI 10.3390/axioms3010046

[10] Kou G, Ergu D. AHP/ANP theory and its application in technological and economic development: the 90th anniversary of Thomas L. Saaty. Technological and Economic Development of Economy. 2016;22(5) DOI 10.3846/20294913.2016.1202353

[11] Kusrini. Konsep dan Aplikasi Sistem Pendukung Keputusan, Yogyakarta: C.V Andi Offset, 2007.

[12] Marimin. Teknik dan Aplikasi Pengambilan Keputusan Kriteria Majemuk, Jakarta: PT. Grasindo, 2004.

[13] Asil E K, Shahraki A, Shahgholian K. Ranking Critical Success Factor in Chaos Management using BSC and AHP Method. Management Science Letters. 2013;3(6):1649-1654 DOI 10.5267/j.msl.2013.05.023

[14] Lailia F N, Santoso E B. Penentuan Kawasan Agroindustri Berbasis Komoditas Unggulan Sektor Pertanian di Kabupaten Probolinggo. Jurnal Teknik ITS. 2014;3(2)

[15] Sari D P, Rinawati D I, Arvianto A, Mujur M. Perancangan Sistem Penilaian Kinerja Karyawan dan Pemberian Reward menggunakan Analytical Hierarchy Process (AHP) dan Fuzzy Synthetic Decision Approach. J@ti Undip: Jurnal Teknik Industri. 2014;9(3):181-186 DOI 10.12777/jati.9.3.181-186 
